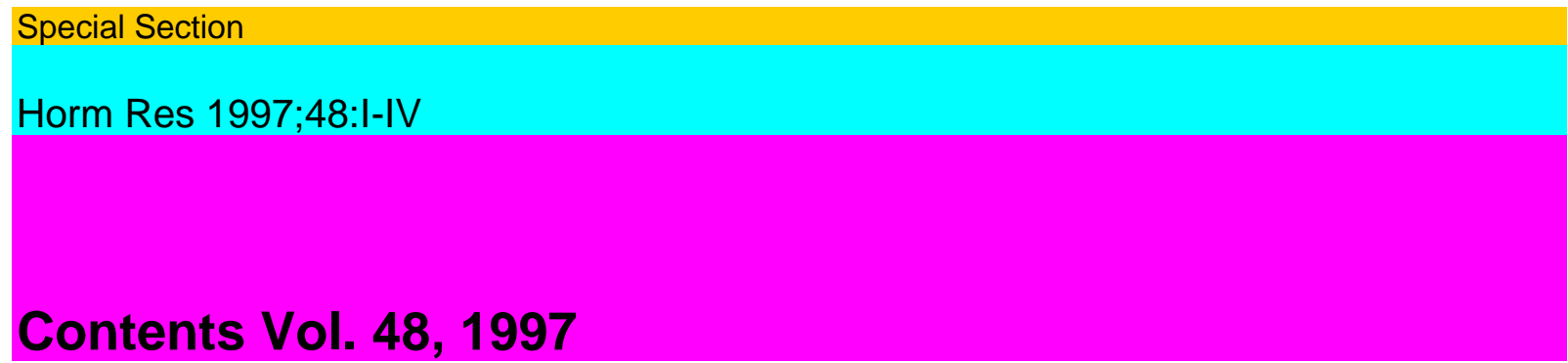

\title{
Hormone, Research
}

No. 1

No. 2

Original Paper

Review

1 Effectiveness and Limitations of the Use of the Gonadotropin-Releasing Hormone Agonist Leuprolide Acetate in the Diagnosis of Delayed Puberty in Males

Lanes, R.; Gunczler, P.; Osuna, J.A.; Palacios, A.; Carrillo, E.; Ramirez, X.; Garcia, C; Paoli, $\mathrm{M}$; Villaroel, O. (Caracas)

5 Effect of Low-Dose Oral and Intravenous Dexamethasone Administration on Growth Hormone Secretion in Children

Pinto, A.-C.A.R.; Weffort, R.F.V.B.; Di Ninno, F.B.; Lengyel, A.-M.J. (São Paulo)

11 Growth Hormone Stimulates Production of Interferon-Gamma by Human Peripheral Mononuclear Cells

Mustafa, A. (Stockholm); Nyberg, F. (Uppsala); Mustafa, M.; Bakhiet, M.; Mustafa, E.;

Winblad, B.; Adem, A. (Stockholm)

16 Influence of Gender on the Correlation between Plasma Growth Hormone Profiles and

Urinary Growth Hormone Excretion

Main, K.M. (Copenhagen); Jansson, C. (Göteborg); Skakkebæk, N.E. (Copenhagen); AlbertssonWikland, K. (Göteborg)

23 Abnormal Metabolism of Type-IV Collagen in Normotensive Non-Insulin-Dependent Diabetes mellitus Patients

Sumida, Y.; Ura, H.; Yano, Y.; Misaki, M.; Shima, T. (Mie)

29 DAX-1 Gene Mutations and Deletions in Japanese Patients with Adrenal Hypoplasia Congenita and Hypogonadotropic Hypogonadism

Kinoshita, E.-i.; Yoshimoto, M.; Motomura, K.; Kawaguchi, T.; Mori, R.; Baba, T. (Nagasaki); Nishijo, K. (Kagawa); Hasegawa, T. (Tokyo); Momoi, T. (Wakayama); Yorihuji, T. (Kyoto) 35 Plasma 3 $\alpha$-Androstanediol Glucuronide in Normal Children and in Congenital Adrenal Hyperplasia due to 21-Hydroxylase Deficiency

Lopes, L.A.; Catzeflis, C; Cicotti, I.; Rey, C; Sizonenko, P.C. (Geneva)

Case Reports

41 A Case of Robinow Syndrome Accompanied by Partial Growth Hormone Insufficiency

Treated with Growth Hormone

Kawai, M.; Yorifuji, T,; Yamanaka, C; Sasaki, H. (Kyoto); Momoi, T. (Wakayama); Furusho, K. (Kyoto)

44 A Case with 47, XXY, del(15)(q11;q13) Karyotype Associated with Prader-Willi Phenotype 
Rego, A. (Vigo); Coll, M.D. (Barcelona); Regal, M. (Vigo); Guitart, M,; Escudero, T. (Barcelona); García-Mayor, R.V. (Vigo)

51 Neonatal Screening for Congenital Hypothyroidism: Results and Perspectives

Delange, F. (Brussels)

Original Paper

62 Factors Determining Pubertal Growth and Final Height in Growth Hormone Treatment of Idiopathic Growth Hormone Deficiency. Analysis of 195 Patients of the Kabi Pharmacia International Growth Study

Ranke, M.B. (Tubingen); Price, D.A. (Manchester); Albertsson-Wikland, K. (Göteborg); Maes, M. (Brussels); Lindberg, A. (Stockholm); on behalf of the International Board of the Kabi Pharmacia International Growth Study

72 Short-Term Changes in Urinary Growth Hormone Excretion and Lower Leg Length in Healthy Children

Ahmed, S.F.; Barnes, S.I.; Wallace, W.H.B.; Kelnar, C.J.H. (Edinburgh)

Case Reports

76 Insulinoma Associated with a Case of Multiple Endocrine Neoplasia Type I: Functional Somatostatin Receptors and Abnormal Glucose-Induced Insulin Secretion

Waeber, G.; Gomez, F.; Bishof-Delaloye, A.; Chaubert, P.; Francke, M.-L.; Haefliger, J.-A.; Scherrer, U.; Centeno, G.; Temler, E.; Nicod, P. (Lausanne)

83 Pubertal Changes in Testicular 3ß-Hydroxysteroid Dehydrogenase Activity in a Male with Classical 3ß-Hydro×ysteroid Dehydrogenase Deficiency Showing Spontaneous Secondary Sexual Maturation

Yoshimoto, M.; Kawaguchi, T.; Mori, R.; Kinoshita, E.-i.; Baba, T. (Nagasaki); Tajima, T.; Fujieda, K. (Sapporo); Suzuki, T.; Sasano, H. (Sendai)

88 Effect of Metformin on Glucose Disposal and

Hyperinsulinaemia in a 14-Year-Old Boy with Acanthosis Nigricans

Lee, P.J.; Cranston, I.; Amiel, S.A. (London); O’Rahilly, S. (Cambridge); Green, A.A. (London)

93 Congress Calendar

Bulletin Board

Congress Calendar 10 Announcement

22 Erratum

KARGER

E-Mail karger@karger.ch Fax+41 613061234 http://www.karger.ch

C1997S. KargerAG, Basel

The list of contents is available at: http://www.karger.ch/journals/hre/hrecont.ht

No. 3

Review

95 Gynecomastia: Pathomechanisms and Treatment Strategies

Mathur, R.; Braunstein, G.D. (Los Angeles, Calif.)

Original Paper

103 Gender-Specific Differences of Serum Leptin in Obese and Normal-Weight Adolescents:

Studies in Type-I Diabetes and Turner Syndrome

Danne, T.; Grüters, A.; Wladimirova, A.; Weber, B. (Berlin); Horn, R.; Mayr, B.; Brabant, G. (Hannover)

108 Effect of Celiac Disease and Gluten-Free Diet on Growth Hormone-Binding Protein, Insulin-Like Growth Factor-I, and Insulin-Like Growth Factor-Binding Proteins 
Federico, G; Favilli, T,; Cinquanta, L.; Ughi, C; Saggese, G. (Pisa) 115 21-Hydroxylase

Deficiency: Screening and Incidence in Israel

Sack, J. (Tel-Aviv); Front, H. (Nathanya); Kaiserman, I. (Tel-Aviv); Schreiber, M. (Nathanya) 120 Clinical and Biological Heterogeneity in

Pseudohypoparathyroidism Syndrome. Results of a Multicenter Study

Marguet, C; Mallet, E.; Basuyau, J.P.; Martin, D.; Leroy, M.; Brunelle, P. (Rouen)

Case Report

131 Elevation of Serum iGF-1 Rather than Sex Steroids Precedes Proliferative Diabetic

Retinopathy in Mauriac's Syndrome

Chantelau, E.; Seppel, T.; Althaus, C. (Düsseldorf); Schönau, E. (Cologne)

Letter to the Editor

135 Features of Malignancy in a Benign Pheochromocytoma

Stumvoll, M.; Fritsche, A. (Tubingen); Pickert, A. (Heilbronn); Overkamp, D. (Tubingen)

Abstracts

137 11th National Meeting of the Italian Society of Pediatric Endocrinology and Diabetology (SIEDP)

Bologna, Italy, September 4-6,1997

154 Congress Calendar

No. 4

Review Paper

155 In Search of Optimal Long-Term Female Hormone

Replacement: The Potential of Selective Estrogen Receptor Modulators

Mitlak, B.H.; Cohen, F.J. (Indianapolis, Ind.)

Original Paper

164 Gonadotropin Secretion in Prepubertal Normal and Agonadal Children Evaluated by

Ultrasensitive Time-Resolved Immunofluoromeiric Assays

Ropelato, M.G.; Escobar, M.E.; Gottlieb, S.; Bergadá, C. (Buenos Aires)

173 GH Treatment Induces Sustained Catch-Up Growth in Children with Intrauterine Growth

Retardation: 7-Year Results

Albanese, A.; Stanhope, R. (London)

178 An Anthropometric Study of Children during Intensive Chemotherapy for Acute

Lymphoblastic Leukaemia

Ahmed, S.F.; Wallace, W.H.B.; Kelnar, C.J.H. (Edinburgh)

184 A Valuable Improvement of Adult Height Prediction Methods in Short Normal Children

Maes, M. (Leuven); Vandeweghe, M. (Ghent); Du Caju, M. (Antwerp); Ernould, C.;

Bourguignon, J.-P. (Liège); Massa, G. (Leuven)

191 Expression of Sex Hormone-Binding Globulin and

Corticosteroid-Binding Globulin mRNAs in Corpus luteum of Human Subjects

Misao, R.; Nakanishi, Y.; Fujimoto, J.; Ichigo, S.; Tamaya, T. (Gifu)

Obituary

Prof. Derek Gupta (1.2.1928-13.5.1997)

Bulletin Board

Congress Calendar

No. 5

Review

199 Mutations in the Calcium-Sensing Receptor and Their Clinical Implications 
Brown, E.M. (Boston, Mass.)

Original Paper

209 Incidence of Dysthyroidism during Interferon Therapy in Chronic Hepatitis C

Benelhadj, S.; Marcellin, P.; Castelnau, C; Colas-Linhart, N.; Benhamou, J.P.; Erlinger, S.; Bok, B. (Clichy)

215 Immunohistochemical Detection of the Melanocortin 1

Receptor in Human Testis, Ovary and Placenta using Specific Monoclonal Antibody

Thörnwall, M.; Dimitriou, A.; Xu, X.; Larsson, E.; Chhajlani, V. (Uppsala/Mölndal)

219 Pubertal Changes in Insulin Secretion and Peripheral Insulin Sensitivity

Potau, N.; Ibañez, L.; Riqué, S.; Carrascosa, A. (Barcelona)

227 Hypoxia-Induced Changes in Insulin-Like Growth Factors and Their Binding Proteins in Pregnant Rats

Tapanainen, P.J. (Stanford, Calif./Oulu); Bang, P.; Muller, H.L.; Wilson, K. (Stanford, Calif.);

Rosenfeld, R.G. (Portland, Oreg.)

Case Report

235 Long-Term Outcome of Male-Limited Gonadotropin-Independent Precocious Puberty

Bertelloni, S.; Baroncelli, G.I. (Pisa); Lala, R. (Turin); Cappa, M. (Rome); Matarazzo, P.; De

Sanctis, C. (Turin); Saggese, G (Pisa)

Bulletin Board

Congress Calendar

Contents

HormResVol. 48, 1997

III

No. 6

Suppl. 1

Original Paper

243 Definitive Diagnosis of Enzymatic Deficiencies of

Steroidogenesis in At-Risk Newborns and Infants by Urinary Marker Analysis Using GC/MSSIM

Maiunowicz, E.M. (Warsaw); Mitkowska, Z. (Krakow); Bal, K. (Warsaw); Nizankowska-Bføz, T. (Rzeszow); Moszczyńska, E. (Warsaw); Iwanicka, Z. (Wrociaw); Romer, T.E. (Warsaw)

252 Measurement of Serum Exon 3-Retaining Growth Hormone-Binding Protein in Children and Adolescents by Radioimmunoassay

Kratzsch, J.; Schreiber, G.; Selisko, T.; Keller, E. (Leipzig); Pflaum, CD.; Strasburger, C.J.

(Munich)

258 Growth before and during Growth Hormone Treatment in Children Operated for

Craniopharyngioma

Hogeveen, M. (Leiden); Noordam, C; Otten, B. (Nijmegen); Wit, J.M.; Massa, G. (Leiden)

263 Androstenedione, Dehydroepiandrosterone Sulfate, and Estradiol Levels throughout Female Puberty: Relation to Height Velocity

Rotteveel, J.; de Ridder, C; Schoute, E.; Deleraarre-van de Waal, H.A. (Amsterdam)

268 Concomitant Evaluation of Plasma Galanin and

Catecholamine Levels during a Cold Pressor Test in Healthy Human Male and Female Subjects

Ceresini, G; Fabbo, A.; Freddi, M.; Maggio, M.; Reali, N; Troglio, G; Valenti, G. (Parma) 
274 Final Height after Growth Hormone Therapy in Short Children: Correlation with Siblings' Height

Zadik, Z.; Zung, A. (Rehovot)

278 Congress Calendar

Author Index Vol. 48,1997

Subject index Vol. 48,1997

Growth and GH Treatment of Children Born Small for Gestational Age, Body Composition

Edited by M.B. Ranke, Tubingen and M.A. Preece, London

Suppl. 2

5th Joint Meeting of the ESPE and LWPES

Edited by M. Ritzen, Stockholm

Suppl. 3

Apoptosis and Reproduction

Edited by H. Kanzaki and A. Miyake, Osaka

Suppl. 4

XVth International Symposium on Endocrinology and Development

Edited by A. Attanasio, Windlesham

Suppl. 5

The Eighth hGH Symposium, Mannheim, April 24-27,1997

Edited by J. Girard, Basel

\section{KAHGEK}

\section{S. Karger}

Medical and Scientific Publishers Basel · Freiburg · Paris · London New York · New Delhi ·

Bangkok Singapore $\cdot$ Tokyo $\cdot$ Sydney

Drug Dosage

The authors and the publisher have exerted every effort to ensure that drug selection and dosage set forth in this text are in accord with current recommendations and practice at the time of publication. However, in view of ongoing research, changes in government regulations, and the constant flow of information relating to drug therapy and drug reactions, the reader is urged to check the package insert for each drug for any change in indications and dosage and for added warnings and precautions. This is particularly important when the recommended agent is a new and/or infrequently employed drug.

All rights reserved.

No part of this publication may be translated into other languages, reproduced or utilized in any form or by any means, electronic or mechanical, including photocopying, recording, mícrocopying, or by any information storage and retrieval system, without permission in writing from the publisher or, in the case of photocopying, direct payment of a specified fee to the Copyright Clearance Center (see 'General Information').

(C) Copyright 1997 by S. Karger AG, P.O. Box, CH-4009 Basel (Switzerland) Printed in Switzerland on acid-free paper by Reinhardt Druck, Basel

IV

Horm Res Vol. 48, 1997

Contents 